\title{
On the boundary of algebraic radicals in topological $(\mathrm{n}, \mathrm{m})$-semirings
}

\author{
Adina POP
}

\section{ABSTRACT.}

The aim of this paper is to investigate some properties for an ideal radical and an ideal radical boundary in a commutative Hausdorff topological $(n, m)$-semiring. We are going to give some generalizations of results due to Shum [Shum, K. P, On the boundary of algebraic radicals in topological semigroups, Acta Mathematica Acad. Scient. Hung., 25 (1974), No. (1-2), 15-19], Chow [Chow, H. L., Remarks on boundaries in semigroups , Period. Math. Hungar., 7 (1976), No. 2, 137-139] relative to semigroups and due Maria S. Pop [Pop, M. S., On boundary in topological n-semigroups, Mathematica, 22 (45) (1980), No. 1, 127-130] relative to $n$-semigroups.

\section{REFERENCES}

[1] Bednarek, B. and Wallace, A. D., Relative ideals and their complements I. Rev. Roum. Math. Pures Appl., 11 (1966), 13-22

[2] Campian, M., Contributii la studiul structurilor $n$-are in algebra si topologie, Ph. D. Thesis, Cluj-Napoca, 1988

[3] Chow, H. L., Remarks on boundaries in semigroups , Period. Math. Hungar., 7 (1976), No. 2, 137-139

[4] Crombez, G., On (n, m) - rings, Abh. Math. Sem. Univ. Hamburg, 37 (1972), 180-199

[5] Crombez, G. and Six, G., On topological n-groups, Abh. Math. Sem. Univ., Hamburg, 41 (1974), No. 1, 115-124

[6] Cupona, G., On topological n-Groups, Bull. Soc. Math. et Phys., R. S. Skopye, XXII (1971), 5-19

[7] Dörnte, W., Untersuchungen über eine verallgemeinerten Gruppenbegrieff, Math. Z., 29 (1928), 1-19

[8] Dudek, D. A and Mukhin, V. V., On topological n-ary semigroups, Quasigroup and Related System, 3 (1996), 73-88

[9] Dulin, B. J. and Mosher, J. R., The Dedekind property for semirings, J. Austral. Math. Soc., 14 (1972), 82-90

[10] Golan, J. S., The theory of semirings with applications in mathematics and theoretical computer science, Kluwer Acad. Publ., Dordrecht/Boston/London, (1999), 381 pp. ISBN 0-7923-5786-8

[11] Mukhin, V. V., On topological n-ary semigroups, Quasigroup and Related System, 4 (1997), 39-49

[12] Opp, M., Verbandstheoretische Behandlung topologischer n-Gruppen, Abh. Math. Sem. Univ., Hamburg, 41 (1974), 124-129

[13] Paalman de Miranda, A. B., Topological semigroups, Math. Centr. Amsterdam, 1964

[14] Pop, M. S., On the prime radical of an ideal in an (m,n)-ring, Bul. Stiint. Univ. Baia Mare, Ser. B, Mat-Inf., XVI (1996), 163-168

[15] Pop, M. S., On boundary in topological n-semigroups, Mathematica, 22 (45) (1980), No. 1, 127-130

[16] Pop, A., Remarks on embeddings theorems of $(m, n)$-semirings, Bul. Stiint. Univ. Baia Mare, Ser. B, Mat-Inf., XVI (2000), No. 2, 297-302

[17] Pop, M. S. and Pop, A., Some properties of generalized semirings, Carpathian J. Math., 24 (2008), No. 3, 397-402

[18] Pop, A., and Pop, M. S., Semiprimary n-semigroups, Carpathian J. Math., 28 (2012), No. 1, 127-132

[19] Sioson, F. M., Cyclic and Homogenous n-Semigroups, Proc. Jap. Acad., 39 (1963), 444-449

[20] Sioson, F. M., Ideals in ( $m+1)$-semigroups, Annali di Mat. Pura et Appl., LXVIII (1965), 161-200

[21] Shum, K. P, On the boundary of algebraic radicals in topological semigroups, Acta Mathematica Acad. Scient. Hung., 25 (1974), No. (1-2), 15-19

DePARTMENT OF MATHEMATICS AND COMPUTER SCIENCE

NORTH University CENTER AT BAIA MARE

TECHNICAL UNIVERSITY OF CLUJ-NAPOCA

Victoriei 76, 430122 BAIA MARE, ROMANIA

E-mail address: adina_p_2006@yahoo.com

* Dedicated to Professor Emeritus Constantin Corduneanu on the occasion of his 85th birthday

Received: 15.07.2013; In revised form: 01.09.2013; Accepted: 04.09.2013

2010 Mathematics Subject Classification. 20N15, 16Y60 ,16Y99, 22A99, 16 N99.

Key words and phrases. Topological $n$-semigroup, topological $(n, m)$-semirings, ideal radical, ideal radical boundary . 